\title{
Fragile States, Infectious Disease and Health Security: The Case for Timor-Leste
}

John M. Quinn ${ }^{1, *}$, Nelson Martins ${ }^{2, * *}$, Mateus Cunha ${ }^{3}$, Michiyo Higuchi ${ }^{4}$, Dan Murphy ${ }^{5}$ and Vladimir Bencko ${ }^{1}$

${ }^{1}$ Prague Center for Global Health, Institute of Hygiene and Epidemiology, First Faculty of Medicine, Charles University in Prague, Studnickova 7, 12800 Prague 2, Czech Republic; E-Mail: john.quinn@lf1.cuni.cz (JMQ), vladimir.bencko@lf1.cuni.cz (VB)

${ }^{2}$ Faculty of Medicine and Health Sciences, Universidade Nacional Timor-Leste, Dili, Timor-Leste; School of Public Health and Community Medicine, Level 2, Samuels Building, The University of New South Wales, Sydney NSW 2052, Australia; E-mail: lalatak61@hotmail.com

** Former Minister of Health for the Democratic Republic of Timor-Leste 2007-2012

${ }^{3}$ Ministry of Health, Dili, Democratic Republic of Timor-Leste; E-Mail: cunha2009ph@gmail.com

${ }^{4}$ Department of Public Health and Health Systems, Nagoya University School of Medicine, 466-8550 Aichi, Japan; E-mail: m.m.higuchi@med.nagoya-u.ac.jp

${ }^{5}$ Medical Director, Bairo Pite Clinic, Dili, Timor-Leste; E-mail: drdanmurphy@yahoo.com

* Corresponding Author: E-Mail: john.quinn@lf1.cuni.cz; Tel.: +420 608246032; Tel.2: +1 6307479081

Submitted: 3 October 2013 | In revised form: 5 February 2014 | Accepted: 6 February 2014 |

Published: 21 April 2014

\begin{abstract}
Timor-Leste is a very young and developing nation state. Endemic infectious disease and weakened health security coupled with its growing and inclusive public institutions keep Timor-Leste fragile and in transition on the spectrum of state stability. The objective here is to systematically review Timor-Leste's state and public health successes, showing how a fragile state can consistently improve its status on the continuum of stability and improve health security for the population. The case study follows a state case study approach, together with a disease burden review and a basic description of the health portrait in relation to Timor-Leste's fragile state status. Disease burden and health security are directly proportional to state stability and indirectly proportional to state failure. Timor-Leste is a clear example of how public health can feed into increased state stability. Our discussion attempts to describe how the weak and fragile island nation of Timor-Leste can continue on its current path of transition to state stability by increasing health security for its citizens. We surmise that this can be realized when public policy focuses on primary healthcare access, inclusive state institutions, basic hygiene and preventative vaccination programs. Based on our review, the core findings indicate that by
\end{abstract}


increasing health security, a positive feedback loop of state stability follows. The use of TimorLeste as a case study better describes the connection between public health and health security; and state stability, development and inclusive state institutions that promote health security.

Keywords: development medicine; fragile and failed states; global public health; health security; public health policy

\section{Background: Fragile and Failed States in the Global Public Health Context}

The broad, and relatively new concepts found in interdisciplinary literature on the global public health debate, of health security, human security, economic security, sustainable development and fragile and failed states remain elusive. 'Sustainable' means to be upheld and maintained at a certain level. A sustainable model in healthcare is one that receives input, possibly from the state and other stakeholders, provides a service and standard of care and is ready and able to continually provide that service in a cycle system with inputs, outputs and health security offered to a certain level for patients or end-users. There are no universally agreed-upon definitions; these concepts are hotly debated, inconsistent, disputed and pose difficulty in offering accurate descriptions for discussion across disciplines. For the purposes of this paper and in order to remain within the framework of the current global public health debate, we define health security as the access to essential health services and protection from environmental and behavioral risks that diminish public health $[1,2]$. This definition frames health security as an aspect of human security, which includes core features such as freedom from want, "and access to life saving clinical and public health interventions" [3].

Plainly, health and human security converge in definitions as the adequate access to healthcare resources. This is grounded in community-based primary healthcare and basic hygiene access, and emphasizes the protection of populations against external and internal threats of conflict and the threat of structural violence. Health and human security protect against oppressive state regimes, failing state systems and failing extractive state institutions; protect against infectious disease and pandemics; and in general provide the most basic in public health and collective security. Structural violence is the set of systemic sociopolitical, economic, legal, religious and cultural norms that harm, disadvantage and limit individuals, groups and societies from reaching their full potential $[4,5]$. Structural violence is often embedded in longstanding ubiquitous social structures, normalized by exclusive state institutions [6].

The relationship between health security and state stability is directionally proportional-as health security increases across a population and state, the stability of the state is bolstered, even if only temporarily, and this feeds into a positive feedback loop to further strengthen the state's institutional capacity and stability, which must be embedded in inclusive state institutions for its citizens. What we see when looking into the recent past of Timor-Leste is an improvement in its health security, even if only slightly, against other states in the region, although it is still highly dependent upon aid and external support. This is leading to state stability in a positive feedback loop gaining traction to further strengthen the state's stability and subsequent health security. This relationship is represented pictorially in Table 1.

This paper concludes that the state is the final de facto vassal to offer inclusive institutions that can engender an environment of health security. Corrupt states with corrupt and exclusive state institutions reduce health and human security and may isolate subgroups in the community and society. The private and philanthropic sectors do not offer a sustainable and equitable solution to provide basic healthcare programming and infrastructure; however, a stable state with inclusive democratic practices for its population can offer health security.

Health security has evolved over time, so it encompasses many entities that make up the present nexus of health and security. The United Nations (UN), World Health Organization (WHO), Asia-Pacific Economic Cooperation (APEC), and the European Union (EU) approach a health security definition within specific areas: emerging diseases; global infectious diseases; deliberate release of chemical and biological materials; violence, conflict, and humanitarian emergencies; natural disasters and environmental change; and radioactive accidents [7-9]. Environmental degradation may pose the largest threat to health security at present and in the future and is a cross-cutting theme throughout global human, food, economic and health security.

Global infectious diseases are those that are transmissible and communicable between people due to the presence and growth of a pathogen; examples being bacteria, fungi, parasites or a virus that causes an infection [10]. Communicable diseases differ from non-communicable diseases (NCD), which are not transmissible from person-to-person via any vector or pathogen; they are far more numerous and are related to the environment, social behavior and eco- 
nomics. Due to poorly understood economic stressors and other unidentified factors, NCDs are breaking out in the least developed and developing nations, where communicable disease incidence and prevalence previously dominated the risk profile. It is true that infectious and communicable disease is truly global, given the porous nature of state borders and the increasing movement of people globally. Infectious disease is no longer limited to the tropics and cardiovascular disease, once encountered only in the developed world, is no longer unseen in developing nation states; it is its own epidemic.

Examples of non-communicable diseases (NCDs) include hypertension, obesity, diabetes, and cancer (although some cancer/malignancies are found to be caused or otherwise contributed to by viral strains), among many others. NCDs are not the focus of this case study as the direct link with state fragility or failure is not as clear. With this, it is understood that the incidence of trauma and trauma-related injuries and death, classified as non-communicable disease, is indeed higher in regions and states characterized by fragility and instability. Trauma-related morbidity and mortality might be significant in fragile and failed states, and may influence health security and subsequent state stability over time. There are many factors that may contribute to trauma morbidity such as the age of the population, health and safety standards and practices, state infrastructure, violence, access to munitions, gender-based intuitional violence, and many other factors. However, this paper focuses on infectious diseases, basic public health structure and institutions, and the link between these factors and state stability.

The present literature does not offer a clear causal link between infectious disease and state fragility or failure, and increased infectious disease does not necessarily lead to violence or state collapse ([11] $\mathrm{p}$. 208). Provision adequate health security by a state to its population is the first line of defense against public health emergencies and is a core component in providing human security at the most basic levels-this holds true even though global policymakers and public health professionals do not always agree on accepted definitions.

Furthermore, food security and poverty in general are also aspects of health and human security. Food security encompasses adequate access to food, food markets and sustainable agriculture, including environmental sustainability. Poverty is loosely defined as having limited or no financial capital, no access to capital or equitable finance, and no access to adequate and equitable work; the consequence of which is to lose human, food and health security as a result of these deficiencies [12]. Food security is obtained when all people at all times have access to sufficient, safe, nutritious food to maintain a healthy and active life, as well as adequate water and sanitation [13]. Food security is a complex sustainable development issue. It is linked to health security through malnutrition, human growth and development, the immune system and disease susceptibility, but it is also linked to sustainable economic development, environmental integrity, equitable trade and finance.

Sustainable development is the equitable and democratic progress that focuses on increasing living standards and positive growth, is consistent, is evenly spread across communities and populations, and does not rapidly diminish natural resources, human capital or otherwise cause creative destruction on the short or long term [14-16]. Sustainable development is not just a humanitarian concern; healthy populations are an essential aspect of economic development and global order and stability.

Economic security is the collective concern for the economic well being between states and their populations; mankind has a common concern for the economic well-being of states and the belief that economic insecurity breeds state and individual instability, conflict and violence. Economic security in the context of public policy and global health is the ability of a nation state to follow its choice of policies in order to develop the national economy and globally compete as desired $[17,18]$. At a personal level, economic security is understood as having access to work, financial resources or enough income to support a consistent standard of living, and includes financial solvency, future access to work and cash-flow.

Labelling a state as 'fragile' or 'failed' risks excluding it from the international community by suggesting it is no longer able to appropriately receive or process money, aid or goods from donors. Using this method, states are not branded as 'failed' or 'stable', but rather are placed on a continuum of stability. At the bottom of the scale are fragile states in danger of failure, whereas near the middle of the scale are those which are developing towards stability. Towards the top of the scale are the states which are the most stable-for now.

State fragility and potential failure must be put in context on the spectrum of state fragility, taking into account multiple matrices of data for comparison and analysis, and understanding that each state has a myriad of complex variables to overcome. State fragility and failure must be put in context and assessed using quantitative or semi-quantitative measures that permit comparison between countries. This enables us to assess the vulnerabilities of each country. Data indicators used to measure state fragility and failure in the main instrument of this research paper are summarized in Table 1. 
Table 1. Indicators used to measure state fragility and state failure as listed in the US Fund for Peace, Failed States Index 2012.

\begin{tabular}{|c|c|c|}
\hline Social & Economic & Political and Military \\
\hline \multirow{7}{*}{$\begin{array}{l}\text { Demographic pressure, } \\
\text { natural disasters and } \\
\text { environmental degradation } \\
\text { Disease and public health } \\
\text { Food scarcity, malnutrition } \\
\text { Mortality } \\
\text { Refugees and internally } \\
\text { displaced persons }\end{array}$} & \multirow{2}{*}{$\begin{array}{l}\text { Uneven economic development } \\
\text { Slum population }\end{array}$} & State legitimacy \\
\hline & & Corruption \\
\hline & \multirow{3}{*}{$\begin{array}{l}\text { Access to improved services } \\
\text { Poverty and economic decline } \\
\text { Government debt }\end{array}$} & Government effectiveness \\
\hline & & Political participation \\
\hline & & Drug trade and illicit economy \\
\hline & \multirow{2}{*}{$\begin{array}{l}\text { Unemployment, youth } \\
\text { employment }\end{array}$} & Protests and demonstrations \\
\hline & & Public services \\
\hline Group grievances & \multirow{17}{*}{ Purchasing power, inflation } & Water, sanitation, basic infrastructure and \\
\hline \multirow{16}{*}{$\begin{array}{l}\text { Human flight and brain } \\
\text { drain }\end{array}$} & & energy \\
\hline & & Quality of healthcare \\
\hline & & Human rights and rule of law \\
\hline & & Civil liberties and political freedoms \\
\hline & & Human trafficking \\
\hline & & Incarceration, torture and executions \\
\hline & & Security apparatus \\
\hline & & Internal conflict, riots and protests \\
\hline & & Rebel activity, military coups, bombings \\
\hline & & Factionalized elites \\
\hline & & External intervention \\
\hline & & Foreign assistance, peacekeeper presence \\
\hline & & Foreign military intervention \\
\hline & & UN presence \\
\hline & & Sanctions \\
\hline & & State credit rating \\
\hline
\end{tabular}

Table 1 is not exhaustive and highlights only the core components of the present research and analysis ranking state fragility and failure; many indicators are still contested and under debate throughout the literature.

However, common features of fragile and failed states are that they are wrought in crisis and may exhibit geographical, physical and fundamental economic constraints, internal strife, gross management flaws, overgrown greed and despotism, handicapping nepotism, debilitating external attack and lack of health for their people $[19,20]$. When nation-states are consumed by violence, they cease to deliver basic human or health security, or any level of public health; these governments lose credibility, and the state becomes questionable and illegitimate in the hearts and minds of its citizens [21,22]. Furthermore, fragile states experience a slow disappearance of state insti- tutions and a breakdown of rule of law, which leads to a deteriorating health security situation $[14,23,24]$. Economic strife and human conflict threaten health security and lead to an increase in infectious disease, physical trauma, malnourishment and mental health disorders [15,25-28].

To sum up, the combination of deteriorating health, human, food and economic security contribute to the situation of fragile states [29]. This paper is a qualitative review of a country case study and the strength of its state institutions and public health successes, which demonstrate how a fragile state can improve and stabilize in a post-conflict setting through health security.

\section{Objective}

To describe infectious disease and health security in 
Timor-Leste and juxtapose it to state stability status, as ranked on the Failed States Index (FSI). TimorLeste has experienced significant institutional and state successes. These successes have led to direct public health successes in a positive feedback loop, engendering more state stability. Institutional and program successes in public health that have improved state stability are described.

Regionally, as China and the United States vie for power and influence throughout the Pacific Region, smaller states such as Timor-Leste are greatly influenced by private and public state and non-state actors levying for control of violence and power, as well as regional authority. When left untreated, state fragility can threaten health security, collective growth, stability and regional order. If public health policy is not further addressed in Timor-Leste in order to continue growth and strengthening of public institutions and public health infrastructure, the many gains of stability may be lost and fragility of the state may worsen or fail.

\section{Methods}

We will carry out a state case study and review and qualitatively describe the disease burden and basic health security portrait, and then place these elements within the continuum of state stability, fragility or failure. This will bedone by taking a systemic approach and critically evaluating data from the Ministry of Health in Timor-Leste, with a direct input from the former Minster of Health, the Immunization Program leadership in Timor-Leste, two qualitative regional health assessments (which occurred in February and May 2011), other Timorese health experts, a review of the literature and data published by the UN, WHO, UNICEF, and the Fund for Peace's.

Failed States Index (FSI), the main research instrument used.

The literature review will include infectious diseases endemic to Timor-Leste, new and present challenges and state successes through institutions in post-conflict countries after 1945 . Finally, a basic review of recent social, political and economic events will be made, in order to place recent state success within their context and to provide a framework of state stability and public health infrastructure through primary healthcare access programs. In turn, this will allow the proposal of a state stability policy for future successes and improved health security.

\subsection{Failed State Index (FSI)}

The Fund for Peace publishes the annual Failed States Index (FSI). The Index assesses all countries in terms of the pressures they experience and, ultimately, their aggregate susceptibility to state failure. There are multiple metrics that are based upon key social, political and economic indicators that make up this index (see Table 1). The FSI then ranks countries using a Composite Score (CSxxx), where a higher score indicates a state's greater inclination towards failure. There are many indices that track fragility and state failure, but the Fund for Peace's FSI offers a mainstream, accepted and inclusive set of metrics based on a sound methodology. Those states which experience drastic food and other commodity price fluctuations, economic distortion and disparity in social, health or political areas, or food riots and public health crises top the FSI list. The entire top third of the states listed on the Failed States Index are either fragile or near failure and are experiencing conflict, war, fragile post-conflict status or, at the very least, political and socioeconomic unrest and violence. The FSI does not predict state failure but rather describes state fragility.

It must be noted that the FSI is controversial and some opponents lament that describing state fragility or failure is nothing but an academic exercise of futility when dealing with state security and development in complex situations and in a complex global arena-even more so when dealing with public health. The data used is indeed open source, some from direct government sources and possibly not sound or otherwise questionable in reporting, while others are from NGOs and may be inconsistent in nature. However, the key indicators of external pressure and capacity realities in governance found within the FSI are directly related to health security for their citizens, overall potential for state stability, and the potential for an improving health security situation.

\section{Results}

\subsection{Timor-Leste-The Recent Past}

As public health programs and institutional stability increases, state stability increases; as public health institutions weaken and, consequently, public health indicators decrease, state stability decreases.

Timor-Leste is a relatively small tropical island state just north of Australia and attached to Indonesia, with a remote and detached Oecussa region bound by Indonesia to the south and east, and the sea to the west. The effects of Indonesian rule on Timor-Leste were vast and multifaceted, and are still today being debated in social science circles. While it is true, that there were many failings across ethnic and religious groups, and in terms of state institutions, this does not fall within the scope of the present paper. However, the use of violence by the Indonesian state and lack of access to state institutions, especially in the public health sector, for Christian Timorese are not quantifiable for the time of Indonesian rule and systemic violence. Access to public health infrastructure during Indonesian rule was near non-existent throughout rural Timor and only available to the politically connected and wealthy in the regional capital, Dili. In the post-2002 health system, confidence remained rather low as access has been plagued by 
violence and ongoing infrastructure impediments, with aid and the humanitarian sector helping unevenly with some institutional shortcomings. It is difficult to assess and appraise public confidence in the healthcare system and confidence across religious and ethnic minorities for the transition period from 2002 to 2011. However, the death rate reduction and access to primary prevention schemes found in the data table below do provide evidence of improved institutional capacity and overall public health improvement for the population.

The Revolutionary Front for an Independent East Timor (FRETILIN) was formed and tried to push out an invading Indonesia in the 1970's. The US and Soviet Union did little to abate the Indonesian takeover and the Secretary of State at the time, Henry Kissinger, discussed East Timor and did not protest the Indonesian President Suharto in reference to the strategic Indonesian invasion and takeover in 1974 [30]. In late 1975, the UN Security Council called on Indonesia to withdraw its troops from East Timor and to summarily stop all acts of war and killing.

There was a prolonged war on the island until a UN-, Portuguese- and Indonesian-backed referendum on independence was held in 1999. A majority of Timorese voted for independence, which was answered with violence and conflict, and forced over 300,000 into West Timor as Internal Displaced Peoples (IDPs) and refugees [31]. During the violence, the entire infrastructure, roads, homes, agricultural irrigation, water supply systems, schools, hospitals, markets and nearly $100 \%$ of the country's electrical grid were summarily destroyed. The destruction of $70 \%$ of the country's infrastructure in 1999 has severely undermined TimorLeste's economic growth and health security. In Autumn 1999, an Australian-led peacekeeping mission, the International Force for East Timor (INTERFET), was deployed in the country and brought the violence to an end.

Timor-Leste joined the United Nations in 2002, became a member of the ASEAN Regional Forum (ARF) in 2005 and is presently an applicant to the ASEAN (Association of Southeast Asian Nations) itself. The building of democratic institutions is growing and development and stability are spreading organically. There is a well-structured policy of reconciliation and forgiveness for the atrocities committed (the Commission for Reception, Truth and Reconciliation; Comissão de Acolhimento, Verdade e Reconciliação, (AVR). Significant progress has been made in reunifying the country after multiple acts of violence threatened to destabilize it, although concerns remain about overall accountability and gender discrimination moving forward.

For example, in early 2006, approximately 700 military personnel petitioned President Gusmao to address complaints of discrimination, which flared into more street violence. There were additional deaths, widespread destruction of property, and the continued displacement of thousands of Dili residents, as well as a decrease in health security; almost $10 \%$ of the country's population became IDPs. In most complex emergencies, public health intervention focuses on the immediate health needs, not underlying conditions and systemic issues [32]. This is best illustrated by the gender based violence and maternal and antenatal care, which was lacking during the crisis. At the time, there was reduced coordination, and a lack of public health dialogue and of advocacy around sensitive reproductive health issues-the need to strengthen neglected areas and the inclusion of all components of sexual and reproductive health provides a foundation to respond to crises [33,34]. At this stage, health security was at significant risk and health infrastructure was decaying substantially; the fragile state of Timor-Leste was teetering on state failure.

Before such failure occurred, the Government of Timor-Leste asked the Governments of Australia, Malaysia, New Zealand, and Portugal to send security forces to stabilize the country. In late summer 2006, the UN Security Council passed Resolution 1704, creating the United Nations Integrated Mission in Timor-Leste (UNMIT). Its mandate included assisting with the restoration of stability, rebuilding the institutions comprising the security sector, supporting the Government of Timor-Leste in conducting presidential and parliamentary elections, and achieving accountability for the crimes against humanity and other atrocities committed in 1999 [35,36].

This mandate included a major policing unit with shared influence and successIn early spring 2011, UNMIT completed its handover of executive policing authority back to the Timorese, effectively declaring Timor-Leste's security apparatus' stable and capable of maintaining rule of law to an international standard. Despite significant global pessimism about UNbacked institutions and bureaucracy, the case can made here that the fragile, near failed state of TimorLeste is a fledgling still moving forward with internationally recognized and UN-backed institutions, which have focused government support and have produced stable outcomes. Resuscitating fragile and failed states starts with the prevention of collapse and restructuring or supporting weak-but-still-growing institutions. In Timor-Leste the efforts made by the Timorese and supported by the UN and coalition countries have worked, and have met or exceeded expectations. Similar positive trends of development in public health infrastructure and can enable further quantified gains to feed into a positive feedback loop and stabilize, and can lead to broader health security and more firmly root state stability.

Timor-Leste is not presently in a lasting state of social unrest or violent conflict. However, its postconflict status and elements of fragility, combined with only a budding democratic infrastructure, are at risk of being pushed towards failure if further investment is not made to secure health security for its citizens. Timor-Leste $\left(\mathrm{FSI}_{2012}=28 ; \mathrm{CS}_{92.7}\right)$ differs from its land 
neighbor Indonesia $\left(\mathrm{FSI}_{2012}=63 ; \mathrm{CS}_{80.6}\right)$, nearby Papua New Guinea $\left(\mathrm{FSI}_{2012}=54 ; \mathrm{CS}_{83.7}\right)$ or the Philippines $\left(\mathrm{FSI}_{2012}=56 ; \mathrm{CS}_{83.2}\right)$ greatly. Globally, Timor-Leste is ranked before Nepal $\left(\mathrm{FSI}_{2012}=27\right.$; $\mathrm{CS}_{93}$ ) and after Bangladesh $\left(\mathrm{FSI}_{2012}=29 ; \mathrm{CS}_{92.2}\right.$ ) (see Table 2 for regional comparisons). FSI methodologies have evolved since its inception in 2005, yet the core 12 social, economic and political indicators (each split into an average of 14 sub-indicators) have remained the same and quantify these areas. The FSI does help describe the public health situation on the ground in Timor-Leste and does so quantitatively.

Table 2. Country Rankings and Composite scores for 2012 [22].

\begin{tabular}{lll}
\hline Country & $\begin{array}{l}\text { Failed States Index Rank } \\
\text { (the lower the value, the more } \\
\text { fragile the state) }\end{array}$ & $\begin{array}{l}\text { Failed States Index Composite } \\
\text { Score (CSxxx) (higher values } \\
\text { denote increased state fragility) }\end{array}$ \\
\hline Timor-Leste (East Timor) & 28 & 92.7 \\
Indonesia & 63 & 80.6 \\
Papua New Guinea & 54 & 83.7 \\
Solomon Islands & 47 & 85.6 \\
Philippines & 56 & 83.2 \\
China & 76 & 78.3 \\
Malaysia & 110 & 68.5 \\
Brunei & 123 & 64.1 \\
Singapore & 157 & 35.6 \\
Australia & 165 & 29.2 \\
New Zealand & 171 & 25.6 \\
\hline
\end{tabular}

With a population of roughly 1.2 million, half the adult population illiterate, a third of the population urbanized in the capital Dili, GDP per capita of less than $\$ 1000$ and a median age of 22 years, the recipe for social and economic instability is clear and the necessity of improvements in public health is policy evident.

Public health leadership, primary healthcare access, vaccination and immunization program compliance and overall inclusive institutional capacity building are still in a state of fragile growth in Timor-Leste. Preventable disease through vaccination programs and basic public health and hygiene measures such as clean water, toilets, access to night-time mosquito nets or repellents, health educational programs, electricity, and affordable primary healthcare access can help ensure health security and can stabilize fragile states. In the case of Timor-Leste, these basic health measures and indicators of health security have been improving since cessation of its recent violent past. However, in order to completely resuscitate this fledgling state and put on a sustainable trajectory of permanency, continued support of inclusive state institutions and primary healthcare prevention programs must be pursued diligently, both by the state and in aid programming schemes.

The health and social demographics in Timor-Leste define its public health portrait. A majority of the population identify as Roman Catholic, greatly influencing maternal and child health in terms of contraception practices and cultural acceptance. Language choices for healthcare literature, education and public health campaigns (promoting, for example, seatbelts, water hygiene and medication compliance) are difficult as Portuguese, Bahasa Indonesia, English, Tetum and other natives languages are all spoken with varying fluency by different communities [26]. This linguistic diversity is a challenge to public health teams that work throughout the country, including the Ministry of Health, and makes it difficult for any formal and unified health guidelines to be disseminated throughout the districts.

The necessary conditions for a state to reverse its course and achieve stability-the recognition and legitimacy of the transitional administration and executive branch, social cohesion within the state, the small size of the country, and coordination facilitated by a high level of consensus among all actors, are all readily observed in Timor-Leste [37]. The public health and epidemiological profile of the country influences the health security situation and is better described by highlighting the gains made in state stability.

\subsection{Timor-Leste's Public Health Infrastructure}

While public health and health security deteriorated and most of the population relied heavily on humanitarian-based health services backed by the Australian led peace force, scattered volunteer doctors, and a community clinic, state stability faltered (Timor-Leste FSI historical data: $\left(\mathrm{FSI}_{2007}=20 ; \mathrm{CS}_{94.9}\right)^{\mathrm{i}}\left(\mathrm{FSI}_{2008}=25\right.$; $\left.\mathrm{CS}_{93.8}\right),\left(\mathrm{FSI}_{2009}=20 ; \mathrm{CS}_{97.2}\right),\left(\mathrm{FSI}_{2010}=18 ; \mathrm{CS}_{98.2}\right)$, 
$\left(\mathrm{FSI}_{2011}=23 ; \mathrm{CS}_{94.9}\right)$ [22]). There was a significant climb of 10 ranking points (from 18 to 28, while aggregate values slid from 98.2 to 92.7 ) between 2010 and $2012\left(\mathrm{FSI}_{2010}=18 ; \mathrm{CS}_{98.2}\right.$ and $\mathrm{FSI}_{2012}=28$; $\left.\mathrm{CS}_{92.7}\right)$. This may be in part due to the 'State Legitimacy' score improving as the first anti-corruption minister took office, as well as a reduction in the crime rate, which was reported to have dropped by $20 \%$ in 2011 , and the third round of free and fair elections, which were completed in summer 2012 without major violence.

The UN Transitional Administration in East Timor (UNTAET) supported a transition from humanitarianbased healthcare services towards an indigenous and sustainable infrastructure, which had varying success. In 2005, the Cuban Government offered to train 1000 medical doctors, open a faculty of medicine, and send roughly 200 medical doctors (including specialists) to work in rural- and sub-district community health centers and hospitals. In 2010, the first returning Timorese doctors educated in Cuba were armed with medical knowledge but scant medical mentors, whose role was also to offer sustainability, while the Cuban doctors sent to rural districts sometimes found life and medical practice for wages in the capital, outside the government program, to be a more attractive option.

There are scattered foreign surgeons and other medical specialists found scattered throughout Dili, however, an inadequate number remain in the health system regularly or consistently to help improve health security to a sustainable level. There is no reliable data on the number of doctors per capita, but some estimates gauge that there is one physician for every 10,000 people. The requirement for welltrained, adequate and consistent medical staff, from general and specialist surgeons to family practice physicians, to ensure human security is significant.

This major healthcare workforce deficiency has partially been answered by the establishment of a Faculty of Medicine in 2005; a Faculty of Public Health in 2004; a School of Nursing and School of Midwifery in 2008; and the recent establishment of a Cabinet of Health Research and Development (CHRD), the first health research institute in Timor-Leste [38]. The CHRD seeks to further assist the use of public health research data to inform decision makers and to develop and enhance ethical, sustainable and consistent public health policy. The Ministry of Health has also provided more than 2,000 scholarships for undergraduate and post-graduate students, including 20 medical specialists who are to complete their medical training in Indonesia, Malaysia, Papua New Guinea and Fiji. The opening of these ministerial-lead and government-backed programs and educational institutions are a great example of how fragile states can develop and stabilize, moving away from failure with the establishment of public health initiatives, underscored by government institutions and private partnerships, which help build capacity and create a better environment for improved health security.

Clinics, both public and private and regardless of specialization, constantly receive patients with a range of problems; among others, newborns and infants suffering from preventable and treatable Acute Respiratory Distress Syndrome (ARDS), Miliary Tuberculosis, Tuberculosis in the bone (Pott's Disease), chronic anemic states in children and mothers, unknown tumors and neoplasia, disfiguring physical trauma, mental health and many other preventable or otherwise treatable illnesses. The disease burden poses a liability for the healthcare infrastructure. In postconflict states, mental health and psychosocial trauma are omnipresent, yet Timor-Leste lacks capacity for mental health services [39]. Timor-Leste lacks a focused and all inclusive mental health campaign to promote mental health, reduce the cultural taboos of mental illness, and offer those who are suffering from mental health illnesses adequate resources for effective diagnosis and treatment.

\subsection{Food Security and Malnourishment}

Malnourishment is food insecurity to the point where one cannot grow, function or develop normally. Malnourishment can also take the form of overconsumption of food, leading to the NCD of obesity and many other health conditions. Prone to drought, flooding, and natural disaster, the risk to Timor-Leste's food security is exacerbated by poor infrastructure and high rates of poverty [22]. Food security can greatly affect child and maternal health as social and cultural factors influence resource allocation among children and consequently affect their health in rural Timor-Leste [40]. Adequate access to vitamin A and nutritious food that promotes growth and human development is still a challenge for some, with $37 \%$ of the population lacking adequate access.

However, in the FSI, Timor-Leste's Demographic Pressures score dropped slightly as the opening of a food plant in 2010 as part of in a joint venture with the World Food Programme (WFP) increased local food capacity; nevertheless, $43 \%$ of the population are reported to be food insecure $[22,41]$. This is coupled with a US $\$ 5.6$ million grant provided by the International Fund for Agricultural Development (IFAD) providing to improve food security for poor maize growing households; the project aims to improve food security for communities which experience a 'hungry season' of up to three months without sufficient food stores [42].

Food security and health security are directly proportional. Timor-Leste still relies on international assistance for many sectors, including efforts to feed its population, and is unlikely to become self-reliant in the near future, as only roughly $10 \%$ of its area is arable land and it has an inadequate agricultural infrastructure. Food security will greatly affect health security in urban and rural Timor-Leste, and state 
stability will be influenced by food security or insecurity. The need for continued support for sustainable agriculture programs and development of the agricultural sector will increase food security and state stability [43]. Conflict engenders predictable health indicator patterns and Timor-Leste is no exception. Selected health indicators relating to basic hygiene and food security characteristics are found in Table 3.

Table 3. Selected Health Indicators: Timor-Leste.

\begin{tabular}{l} 
Indicator \\
\hline $\begin{array}{l}\text { Prevalence of Child Malnutrition } \\
\text { (Percentage of under-5 year olds } \\
\text { uderweight) (2005-2011) [44] }\end{array}$ \\
Population Undernourished \\
(Percentage of Total Population) \\
(2006-2008) [45] \\
Population With Sustainable \\
Access to Improved Sanitation \\
(2010) [44]
\end{tabular}

Population With Sustainable Access to an Improved Water Source (2010)

\begin{tabular}{ll} 
Prevalence & Comment \\
\hline $43.7 \%$ & The percentage of children under the age of five whose \\
& $\begin{array}{l}\text { weight for his/her age is more than two standard } \\
\text { deviations below the WHO Child Growth Standards } \\
\text { median }\end{array}$
\end{tabular}

$31 \% \quad$ Undernourished Population: individuals whose food intake is chronically insufficient to meet their minimum energy requirements

$69 \%$ The percentage of the population with access to adequate excreta disposal facilities, such as a connection to a sewer or septic tank system, a pour-flush latrine, a simple pit latrine or a ventilated improved pit latrine (considered adequate if it is private or shared and not public, and can effectively prevent human, animal and insect contact with excreta. Improved sanitation includes connection to public sewers, connection to septic systems, pour-flush latrines, simple pit latrines, and ventilated improved pit latrines. Not considered as improved sanitation are service or bucket latrines (where excreta is manually removed), public latrines, and open latrines [46].

$69 \% \quad$ The percentage of the population with sustainable access to an improved water source (household connections, public standpipes, boreholes, protected dug wells, protected springs and rainwater collection). Unimproved water sources are unprotected wells, unprotected springs, vendor-provided water, bottled water (unless water for other uses is available from an improved source), and tanker truck-provided water [46]

$45 \% \quad$ The percentage of children reached with two doses of vitamin A supplementation.

Vitamin A is an essential nutrient for the proper functioning of the immune system and the healthy growth and development of children. Insufficient intake of vitamin A in children can dramatically increase the risk of death, blindness, and illness, especially from measles and diarrhoea.

36.78 This is in contrast to an estimated (IMR) $=70-95$ per deaths per 1000 live births in 2002 [49]

1,000 live

births

\subsection{Emergency Medical Services: Risks and Barriers to Health Security}

Basic road infrastructure is significantly deficient throughout the country. There is no rail transport, and buses and ad hoc bus transportation is expensive and dangerous. This negatively affects basic public health logistics such as cold-chain management for vaccines and medicines, mobile health teams and emergency response in disasters. Few drivers adhere to safe 
driving practices; a public health seat belt campaign has not yet been securely embraced and many regions and villages have a single unsafe road where children play and village work may be performed connecting them with the rest of the country. It is not yet adequately quantified in the literature, but road traffic accidents and trauma from a lack of implemention of safety standards are anecdotally endemic.

Despite the presence of five major district hospitals equipped with four core specialists, a nurse anesthetist, and despite having some 65 multifunction ambulances based at community health centers in the sub-districts, consistent and comprehensive emergency medical services do not exist and multiple trauma patients must often be transported by their own means to Dili for treatment. Access to consistent and adequate fuel and vehicle maintenance is a major barrier for the ambulance service. Definitive medical treatment and tertiary care for multisystem trauma patients does not exist in Dili and petition must be made for patients to be medically evacuated abroad to receive definitive care. A community-based emergency medical services system implementation with tertiary care services offered in the capital would offer emergency medical services in a sustainable fashion. Poor transport, unsafe practices and access to adequate emergency medical services are all barriers not only to primary healthcare access but to health security in general.

The Burden of Disease in Timor-Leste, a breakdown of infectious and communicable diseases. Infectious and communicable disease is getting worse for much of the resource poor and developing world. This can be observed by looking at health indicators and economic progress across states, taking into special consideration the impact of the global financial crisis. Developing nations may lack finance and systems to effectively address the behavioral, environmental and health systems factors related to health security, which determine the burden of communicable diseases [50]. Timor-Leste faces a severe threat and increased health risk from endemic infectious disease, inadequate hygiene access, and, consequently, decreasing health security and increased state fragility. Its tropical location, isolated population, and diverse ecosystems make it a haven for tropical disease, climate change-related health issues, and barriers to health security. Timor-Leste is highly vulnerable to natural disasters such as earthquakes, tsunamis, floods, landslides and erosion, resulting from the combination of heavy monsoon rain, steep topography and widespread deforestation; these factors also contribute to infectious disease risk. Climate change and environmental degradation also contribute to the disease burden.

Mycobacterium tuberculosis is a pathogen, which causes tuberculosis and is a threat to health security throughout Asia. Due to the resource-poor nature of health services in Timor-Leste, the quantitative disease burden of tuberculosis is impossible to determine on a country-wide basis. Despite the post-conflict national Tuberculosis Control Program [51], infection rates, a lack of medicine, and poor treatment compliance mean that the disease continues to devastate communities [52]. Multidrug-resistant tuberculosis (MDR-TB) is becoming more common and affects a large proportion of the pediatric population, despite a vaccine program; past estimates (diagnoses?) of MDR-TB are a level of at $1.6 \%$ among the newly diagnosed and $14.5 \%$ among those previously treated [53]. Mycobacterium leprae, the pathogen that causes leprosy, a neglected tropical disease afflicting humans since time immemorial, was eliminated as a public health concern in 2010; with a reported prevalence of the disease of 0.83 per 10,000 inhabitants in comparison to 0.75 per 10,000 in the year 2000. If all actors and partners do not stay committed, this threat could return. In Timor-Leste, tuberculosis easily affects pediatric patients under the age of five years and threatens health security and quality of life, and causes death.

Approximately one third of the total population may be infected with tuberculosis. Those that have tuberculosis and HIV/AIDS infection are at the highest risk of disease complications and death. The disease burden of tuberculosis together with HIV/AIDS cannot yet be quantified for Timor-Leste, as disease prevalence is only available as an estimate. Present estimates range from a $0.2 \%$ to $1.5 \%$ HIV infection rate, compared with a rate of $0 \%$ in 2000; the first diagnosis of a patient as HIV positive was reported in 2003. A massive increase in sexually transmitted diseases, such as HIV/AIDS and human pappilomma virus (HPV) may be rising amongst the younger population, with social and demographic shift in the population.

Endemic Malaria, resistant to conventional choloquine treatment and prophylaxis, is also seen throughout Timor-Leste. Malaria is a major global health problem, often exacerbated by political instability, conflict and forced migration. It thrives in fragile and failed states [54]. The cost of prophylaxis is prohibitive for the majority of the population, (foreignbased workers and private sector workers excluded) Use of bed nets at night (when the female mosquito is most actively seeking a blood meal) is still well below $50 \%$ among at-risk groups. Endemic Japanese Encephalitis is seen in many districts as the vaccine is costly Poor access leaves many with central nervous system morbidity for life once infected, should they survive it.

Dengue fever and viral hemorrhagic fevers (VHFs) are endemic. Dengue fever is a most pressing public health issue for Timor-Leste. Almost all other neighboring countries have experienced a fatal outbreak of the disease, but Timor-Leste has experienced recurrent outbreaks with devastating effects in 2005, 2010 and 2012. Dengue fever, carried by the Aedes aegypti mosquito, has high mortality rates in the 
pediatric and geriatric populations. It cannot be cured and treatment is only directed at the symptoms. Prevention of Dengue fever can only be carried out through avoiding the mosquito bite and vector control -there is no vaccine.

Schistosomiasis (Bilharzia) has a global prevalence of roughly 200 million, with 600 million people who swim or work in infected waters at risk. Its prevalence in Timor-Leste has been poorly quantified. This blood fluke infects through the skin and can cause symptoms tanging from a constant itch to multiple system organ failure and death. With environmental degradation and changes to water supply and rivers caused by climate change, leptospirosis incidents of may be rising in the area around Dili and other urban centers. In the event of flash floods, landslides, earthquakes or a tsunami, water borne illnesses increase.

Anemia caused by chronic disease, parasitic infections and malnutrition is possibly at epidemic levels. Many parasitic infections lead to anemia, as do states of malnutrition. Severe anemia can cause death, while in chronic forms it can lead to impaired growth and cognition for the developing brain, and in pregnant women anemia can lead to low birth weight and maternal death [25]. The combination of longstanding anemia, inflammation, and target organ damage causes growth retardation, under-nutrition, and cognitive delays in children, adversely affecting personal, economic and social growth [25].

Leptosporsis is a zoonosis from rats, dogs, livestock and rodents that urinate into water supplies around urban dwellings; it enters the body from infected water supplies through cuts, abrasions, or the eyes or mouth. Leptospiriss can be self-limiting, causing only fever and flu-like illness, but it can also lead to significant disability and multiple organ failure if not diagnosed or treated properly, the best treatment being prevention from exposure [55].

Soil-related Helminth infections (Acariasis, Trichuriasis and Hookworm infections) debilitate many children and leave them socially ostracized and chronically anemic through poor hygiene and lack of prevention or educational resources [56]. Lymphatic filariasis (elephantiasis) causes social ostracization and dysmorphic effects from unnatural swelling of the lymph nodes. This disease is not terribly common in Timor-Leste but many residents are at risk for contracting it through mosquito bites and treatment remains expensive and out-of-reach for rural populations without adequate access to primary healthcare services. If economic opportunity continues to decline in the rural periphery and the Timorese continue to ascend upon the capital Dili in search of work, urban areas may exceed capacity and contribute to the spread of disease. Also, in the event of further social and political strife, incidences of the disease could greatly increase.

Typhoid, treatable with a vaccine widely available in the developed world, is prevalent in Timor-Leste, although under-diagnosed and under-treated. Rabies, from a variety of rabid animals (dogs, cats, bats, etc.) living amongst rural populations is a severe risk to health once patients become exposed through a bite or scratch. Prophylaxis for rabies exists in the form of pre- and post-exposure vaccines, but is very costly and requires significant compliance with painful inoculations and, in the case of post-exposure treatment, prompt medical treatment is mandatory for success. Upon exposure to rabies through saliva (ie. an animal bite), prompt treatment before the virus reaches the peripheral nerve can stop the disease from spreading. However, with poor road infrastructure, no remote medical clinics or the lack of pharmaceutical cold chain management to maintain safe and viable vaccines, this is not possible for much of the at-risk population.

Amebic dysentery is also poorly diagnosed in many medical laboratories, but is very prevalent in Timor. Giardia lamblia, the parasite that causes bloating and diarrhea, is also very common and debilitates many people each year. The disease burden in post conflict and fragile states is significant, and Timor-Leste is no exception. Public health infrastructure and solid, focused governmental policy can alleviate and prevent many of these illnesses through renewed vaccination and immunization efforts, basic health services, and the promotion of hygiene practices.

\subsection{Present Challenges for Health Policy in Timor- Leste}

The United Nations Children's Fund (UNICEF) estimates that only $71 \%$ of children under five with suspected pneumonia are taken to an appropriate healthcare provider at; of this population it is estimated that only $45 \%$ would receive antibiotic treatment of any kind. Globally, pneumonia, and other respiratory infections and diseases are a major contributor to pediatric illness and fatality. UNICEF also estimates that only $63 \%$ of children under five years old with diarrhea received oral rehydration therapy and continued feeding in 2010. Diarrhea and the dehydration associated with it are the number one causes of death in the developing world and can lead to chronic malnourishment, growth and development abnormalities, and an overall lack of health security for children. In Timor-Leste, the risk of pediatric diarrhea and complications such as acute dehydration and death are significant.

In order to address of the growing disease burden, and to increase the access to health services of communities living in the rural and remote areas, the Ministry of Health instituted the Servisu Integradu da Saúde Communitária (Integrated Community Health Services or SISCa) project. Dr. Nelson, Minister of Health from 2007 to 2012, called upon District and Sub-District Administrators, Suco Chiefs and Councils, Aldeia Chiefs, Youth Organizations, Women's Net- 
works and NGOs working within the country for support. Collaboration within government-backed public health programs offered by the SUSCa engenders partnership and disease prevention. However, the gains made will be lost if continued inclusive institutional investment in human and financial capital with clear and sustainable targets and outcomes are not further outlined.

\subsection{Primary Prevention: Vaccination Catastrophe}

The SISCa program provides disease prevention, early treatment and, anecdotally, increases health security. However, disease prevention through vaccination, such as those available for polio and measles, is rarely seen in Timor-Leste. Poor vaccine compliance and/or access to viable vaccines contribute to this epidemic of increasing incidence of preventable illness. These barriers to care, which exacerbate risk factors, lead to a vaccination catastrophe. Primary prevention in the form of vaccination saves lives, reduces disease burden and morbidity, and can eliminate disease when carried out as a sustainable and consistent process.

The World Health Organization (WHO) Expanded Program of Immunization (EPI), realised in collaboration with the UNICEF, the Ministry of Health, and aid agencies in Timor-Leste, focuses on vaccination coverage for children under the age of five against measles, tetanus, diphtheria, polio, tuberculosis and pertussis. Despite significant investment in cold chain management, training, educational resources for parents, and mechanisms to guarantee vaccination compliance and coverage for children, data from UNICEF suggest that only between 66 and $72 \%$ of this population have currently received these basic vaccinations. Less than $46 \%$ of reporting districts have achieved more than $80 \%$ coverage of the third effective dose of the diphtheria, pertussis and tetanus vaccine [57].

When the herd immunity, the total immunity of a population, drops below $90 \%$, the risk of disease outbreak increases logarithmically. Some patients in the population are too sick, immune-compromised or are allergic to be administered the vaccine but a herd immunity of $90 \%$ can protect these otherwise exposed members, as well as at-risk children. The risk of infectious diseases which are totally preventable through vaccine quickly leads to an outbreak when herd immunity is consistently low and more children are at risk of coming into contact with preventable diseases which they are not immunized against.

Table 4 illustrates the risk of preventable infectious disease in Timor-Leste for the vulnerable population of under five year olds. The acute need for a re-focus on primary healthcare and primary prevention through vaccination and immunization against preventable illnesses is highlighted here. Preventable illness and infectious disease threaten state stability in TimorLeste by threatening health security.

Table 4. Immunization and Health data: Timor-Leste pediatric population $[49,58-60]$.

\begin{tabular}{ll}
\hline Immunization 2010, 1-year-old children immunized against: TB corresponding vaccines: BCG & $71 \%$ \\
Immunization 2010, 1-year-old children immunized against: DPT corresponding vaccines: DPT1 & $75 \%$ \\
Immunization 2011, 1-year-old children immunized against: DPT corresponding vaccines: DPT3 & $67 \%$ \\
(up to the third dose of vaccine booster) & \\
Immunization 2010, 1-year-old children immunized against: Polio corresponding vaccines: Polio3 & $72 \%$ \\
Immunization 2010, 1-year-old children immunized against: Measles corresponding vaccines: & $66 \%$ \\
Measles & $81 \%$ \\
Immunization 2010, \% newborns protected against tetanus &
\end{tabular}

With this, the comprehensive multi-year plan for immunization, scheduled to be carried out from 20092013, aims to reach national immunization coverage targets which have been established by the Millennium Challenge Corporation (MCC). The MCC's Board of Directors approved the Government of TimorLeste's threshold program proposal in May 2010 and work started in 2011 in the form of the Millennium Challenge Corporation Threshold Program for Immunization (MCC-TPI). Timor-Leste's MCC-TPI, administered by United States Agency for International Development (USAID), is assisting the Ministry of Health in its efforts to increase nationally the coverage of the third and final diphtheria, pertussis and tetanus
(DPT3) vaccine, as well as measles immunization rates (these would increase herd immunity). This project's goal is to achieve a combined national average of $81.5 \%$ coverage for DPT3 and total measles coverage in children below one year of age by 2013. A complementary goal for MCHIP is to strengthen the Expanded Program on Immunization (EPI) to ensure program sustainability.

\section{Discussion}

Timor-Leste has shifted from being a fragile state on the verge of failure to one on a path of sustainable stability. By improving its public health infrastructure, 
programming and health security rooted in disease prevention and primary healthcare access, both health security and state stability will improve. Timor-Leste's public health leadership has helped to establish a programme which must receive continuous support and development to succeed.

As external actors continue to depart from the UN lead mission in 2012, local capacity at all levels must continue to meet the daily challenges and be ever more inclusive, sustainable and broad in scope. A focused developmental approach through public-private partnership and transparency helps build capacity in fragile state settings and engenders state building [61-63].

Humanitarian aid and development are in a state of paradigm shift, with one force pushing for the growth of new sources of aid and loans from middle income countries, private capital and charitable organizations, while the other focuses on the rights of individuals and advocacy of at-risk populations and communities; Timor-Leste can no longer rely on outside aid for public health support and its future state stability prospects. Humanitarianism may even be in a weak state as the global financial crisis has challenged the paradigm of donor financial support and subsequent operations; sustainability is not integrated into this old model of aid. There are aid organizations that focus on little more than maintaining budgets, offering antiquated solutions to complex issues, and keeping projects in a steady state, but not actually fixing any systemic problems [64]. By encouraging inclusive institutional support at the public health level, general capacity building and self-directed growth which reduces the risk of failure, it is possible that a wholly sustainable public health model can engender health security and help solidify state stability by moving away from external non-state and unilateral organization support.

Unilateral actors such as the United States (US) and European Union (EU), as well as multilateral actors like the UN, Asian Development Bank, and the World Bank will be tested with one of the 21st century's largest challenges: development within fragile and failed states. US-based assistance focuses on bolstering stability by strengthening the foundations of good governance, accelerating economic growth, improving the health of citizens, and supporting the professionalization of security forces such developmental support is a good method, but guidance but must be temporary and sustainable.

\subsection{Networks}

"Goodbye conflict, hello development," may be the introduction to the citizens guide to the 2012 budget for Timor-Leste, but many regional challenges remain for the country itself; this is outlined by the fledgling economic and health security of its citizens. In 2010 the G7+ was formed by fragile and failed states in order to create a collective voice and platform to address their particular needs. The G7+ is a voluntary association of countries that are or have been affected by conflict and are now in transition to the next stage of development, the main objective of which is to share experiences and learn from one another, as well as to advocate reforms to the way the international community engages in conflict-affected states [65].

The G7+ promotes democracy, strong institutions and good governance. This is a 'rock-bottom' help network for countries that live with the threat of failure. The Chair of this state support group is TimorLeste's Finance Minister, Emilia Pires, and the focus is on clearly identifying the needs of the these fragile nation-states in order to maintain and develop sustainable policies and inclusive institutions that focus on stability for their citizens.

The G7+ is a state-level support group which draws upon public-private donors and actors and aims to create focused policies which engender stability by ending and preventing conflict. Aid effectiveness is a main priority of the $\mathrm{G} 7+$, with peace and state building as core components. The direct link between Timor-Leste's leadership role in the G7+ and its public health outcomes will not be seen for a decade or more. However, the concept of building strong institutional capacities in state health infrastructure, and the direct and indirect benefits of this capacity growth, is seen in the public health advancements in post-2002 Timor-Leste discussed throughout this paper. The rising presence and leadership of TimorLeste in the G7+ is a clear example of how improvements in public health have lead to sustainable state stability.

\subsection{Present State Challenges}

The elections in mid-March, June and July 2012 were defining moments in the stability of Timor-Leste and for the idea of fragile states stabilizing with the focused backing of inclusive institutions, rule of law, governance and the democratic electoral process. This socio-political transformation in Timor-Leste is seen in safe and fair elections, and will be underscored by political power and wealth being redistributed amongst a variety of competing societal interests [66].

However, political will and democratic process are not the only actors in the direction of state stability. Timor-Leste has received oil and gas revenues from major projects in the Joint Petroleum Development Area that it shares with Australia. The Petroleum Fund is a government-backed program aiming to ensure the sustainable use of oil revenues over the long term. Assets have grown from $\$ 6.9$ billion in 2010, $\$ 8.3$ billion in 2011 and reached over $\$ 10$ billion in 2012 [67]. This steady financial growth has greatly influenced the state's 'Poverty and Decline' level on the FSI matrix and can help improve health security when spent wisely on inclusive policy. It is up to the 
democratically elected government of Timor-Leste to allocate its financial resources in a way that will engender human and health security for its citizens. Economic development and growth in foreign direct investment is significant and can offer sustainable and inclusive state stability.

This paper does not set out to break down and assess the budgetary strategy of Timor-Leste. However, year-on-year, and with the help of oil-resource and foreign direct investment funds and aid, TimorLeste has been able to slowly build a budding infrastructure and pay its healthcare staff to work and become trained in this once war-ravaged country. The Strategic Development Plan has helped pave the way for an investment strategy that focuses strongly on major infrastructure, skills, and structural gaps, which may generate a sustainable private sector and reduce poverty [68].

Despite this economic growth being relatively consistent, this developing economy based on the US dollar is still dependent on government spending and assistance from international donors. Due to significant human capital shortages, not only in healthcare, but also in engineering, legal and other sectors, private sector development is slow to mature, public health-related infrastructure (particularly in terms of power and water) remains wanting, the judicial system is incomplete, and an equal access marketplace or overall business environment remains to be seen. The transition from state fragility to stability is still tenuous and much remains to be done.

\section{Conclusion}

The FSI will not predict future human conflict or state failure but it can better describe state fragility and help focus attention on fragile and failing states for immediate aid and intervention in an effort to prevent state catastrophe. Fragile states have a diminished ability to provide basic services and offer no sustainable means of health security to their citizens. The continued strengthening of government accountability and transparency, and re-focusing on the public health sector are key components of public policy promoting stability. An extremely young state, TimorLeste has struggled to maintain unity in government while fighting greater structural weaknesses, including corruption, political polarization, and dependence on foreign aid. The G7+ offers a platform for fragile and failed states to promote stability through organically constructed institutions and public policy.

Increasing health security will continue to guide

\section{References}

[1] Ng N, Prah Ruger J. Global Health Governance at a Crossroads. Global Health Governance. 2011;3(2):1-35.

[2] Labonté R, Gagnon M. Framing health and foreign
Timor-Leste from fragile to stable statehood. A reinforced public health policy of primary healthcare access, immunizations and increased overall vaccination coverage for the under five-year-old population may increase health security significantly. Timor-Leste clearly illustrates the link between public health institutions and health security and state stability and development. Lessons learned from Timor-Leste's still complex transition from a post-conflict state to a successful nation can provide international leadership an example of which it should take note. Endemic infectious disease, decreased health security and weak but growing public institutions keep Timor-Leste fragile, while new investment and economic prospects, when handled properly and with efficient and appropriate public health policy, may engender state stability and may help to avoid state failure. Health Security is directly linked to state security. Public health policy must be implemented in order to prop up its fledgling public health sector and still growing democratic institutions. Increasing health security through public health can push Timor-Leste out of fragility and engender sustainable economic growth, development and consequently true statehood.

\section{Competing Interests}

The authors declare that they have no competing interests

\section{Author Contributions}

JQ and NM wrote the first draft of the manuscript. MC offered data and data confirmation from the Ministry of Health. VB, DM and MH supported data, organization, methodology and contributed to revising subsequent drafts. All authors approved the final version.

\section{Disclosures}

John Quinn performed a two-phase heath assessment of Timor-Leste in 2011 and presented his findings and solutions to the Minister of Health in May 2011. There are no commercial disclosures or statements to release.

Nelson Martins served as Minister of Health for TimorLeste from 2007 to 2012, the comments and contributions made within this paper are his own and do not necessarily reflect government or ministerial policy, past, present or future.

policy: Lessons for global health diplomacy. Globalization and Health. 2010;6(14):1-19.

[3] Kent G. Freedom from Want: The Human Right to Adequate Food. Washington, DC, USA: Georgetown University Press; 2005.

[4] Galtung J. Violence, peace and peace research. 
Journal of Peace Research. 1969;6;167-191.

[5] Galtung J, Höivik T. Structural and Direct Violence: A note on operationalization. Journal of Peace Research. 1971;8(1)73-76.

[6] Gilligan J. Violence: Reflections on a national epidemic. New York, NY, USA: Vintage Books; 1997.

[7] Aldis W. Health Security as a public health concept: A critical analysis. Health Policy Planning. 2008;23(6):369-375.

[8] Chiu YW, Weng YH, Su YY, Huang CY, Chang YC, Kuo KN. The nature of international health security. Asia Pacific Journal of Clinical Nutrition. 2009;18(4):679-83.

[9] Macrae J. Purity or Political Engagement?: Issues in food and health security interventions in complex political emergencies. Journal of Humanitarian Assistance. 1998. Availaible from: http://sites.tufts.edu/jha/archives/126.

[10] Kasper DL, Fauci AS. Harrison's Infectious Diseases. New York, NY, USA: McGraw-Hill; 2010.

[11] Patrick S. Weak Links: Fragile States, Global Threats and International Security. A Council on Foreign Relations Book. New York, NY, USA: Oxford University Press; 2011.

[12] Quinn JM, Bencko V. Food security, public health, financial regimes and international law. Chapter 23. In: Westra $L$, Soskolne CL, Spady DW, editors. Human Health and Ecological Integrity. London, UK: Earthscan from Routledge; 2012.

[13] Inter-Parliamentary Union. Declaration adopted at the Parliamentarians' Day on the occasion of the World Food Summit. Italian Senate of the Republic. Rome, Italy; 15 November 1996.

[14] Acemoglu D, Robinson JA. Why Nations Fail: The origins of power, prosperity and poverty. London, UK: Profile Books; 2012.

[15] Collier P. The Bottom Billion: Why the poorest countries are failing and what can be done about it. Oxford, UK: Oxford University Press; 2007.

[16] Stiglitz J. Making Globalization Work. New York, NY, USA: Norton; 2006. p. 44.

[17] Akpeninor JO. Modern Concepts of Security. London, UK: Author House; 2012.

[18] Nye JS. Collective Economic Security. International Affairs (Royal Institute of International Affairs) 1974;50(4)584-598.

[19] Gros JG. Towards a taxonomy of failed states in the New World Order: Decaying Somalia, Liberia, Rwanda and Haiti. Third World Quarterly. 1996;17(3):461.

[20] Rotberg RI. State Failure and State Weakness in a time of Terror. World Peace Foundation. Washington, DC, USA: Brookings Institution Press; 2003.

[21] Rotberg RI. When States Fail: Causes and Consequences. Princeton, NJ, USA: Princeton University Press; 2004.
[22] The Fund for Peace. Failed States Index 2011 and Conflict Assessment Indicators: Country analysis indicators and their measures. Washington, DC, USA: The Fund for Peace publication CR-11-14-FS (11-06Q); 2011.

[23] Naim M. Illicit: How Smugglers, Traffickers and Copycats are Hijacking the Global Economy. 1st Edition. New York, NY, USA: Doubleday Press; 2005.

[24] Zartman IW. Cowardly Lions: Missed Opportunities to Prevent Deadly Conflict and State Collapse. London, UK: Lynne Rienner Publisher; 2005.

[25] Hotez PJ. Forgotten People, Forgotten Diseases: The neglected tropical diseases and their impact on global health and development. Washington, DC, USA: George Washington University and Sabin Vaccine Institute, ASM Press; 2008.

[26] Hotez PJ. Vaccines as Instruments of Foreign Policy. European Microbiology Organization (EMBO) Report. 2001;2(10):862-868.

[27] Catalano R. The health effects of economic insecurity. American Public Health Association. American Journal of Public Health. 1991;81(9):1148-1152.

[28] Paris R. Human Security: Paradigm Shift or Hot Air? International Security. 2001;26(2):87-102.

[29] Schrecker T. Multiple crises and global health: New and necessary frontiers of health politics. Global Public Health: An International Journal for Research, Policy and Practice. 2012;7(6):557573. Available from: http://dx.doi.org/10.1080/ 17441692.2012.691524.

[30] Burr W, Evans LE, editors. East Timor Revisited: Ford, Kissinger and the Indonesian Invasion, 1975-1976, Ford and Kissinger Gave Green Light to Indonesia's Invasion of East Timor, 1975: New Documents Detail Conversations with Suharto. Washington, DC, USA: National Security Archive, Electronic Briefing Book No. 62; 6 December 2001.

[31] Human Rights Watch. East Timor: Forced Expulsions to West Timor and the Refugee Crisis. 1 December 1999. Document No. C1107. Available from: http://www.refworld.org/docid/45cc 24ac2.html.

[32] Waldman RJ. Prioritizing health care in complex emergencies. The Lancet. 2001;357(9266): 1427-1429.

[33] Wayte K, Zwi AB, Belton S, Martins J, Martins N, Whelan A, Kelly PM. Conflict and development: Challenges in responding to sexual and reproductive health needs in Timor-Leste. Reproductive Health Matters. 2008;16(31):83-92.

[34] Wild K, Barclay L, Kelly P, Martins N. The tyranny of distance: Maternity waiting homes and access to birthing facilities in rural Timor-Leste. Bulletin of the World Health Organization. 2012;90(2); 97-103. 
[35] UN Security Council. Security Council resolution 1704 (on establishment of the UN Integrated Mission in Timor-Leste (UNMIT)). 25 August 2006. Report No. S/RES/1704.

[36] United States Department of State. Bureau of East Asian and Pacific Affairs: Background Note: Timor-Leste. 11 October 2011. Available from: http://www.state.gov/r/pa/ei/bgn/35878.htm.

[37] Alonso A, Brugha R. Rehabilitating the health system after conflict in East Timor: A shift from NGO to government leadership. Health Policy and Planning. 2006;21(3):206-216.

[38] Martins N, Hawkins Z. Striving for better health through health research in post-conflict TimorLeste. Health Research Policy and Systems. 2012;10(13)1-4. Available from: http:// www.ncbi.nlm.nih.gov/pmc/articles/PMC3359172.

[39] Brooks R, Silove D, Steel Z, Rees S. Explosive anger in postconflict Timor-Leste: Interaction of scoio-economic disadvantage and past human rights-related trauma. Journal of Affective Disorder. 2011;131(1)268-276.

[40] Reghupathy N, Judge DS, Sanders KA, Amaral PC, Schmitt $H$. Child size and household characterization in rural Timor-Leste. American Journal of Human Biology. 2012;24(1):35-41.

[41] da Costa M, Erkskine W, Nesbitt H, Spyckerelle L, do Rosario Ferreira A, Zimenes A, Lopez M. Household food insecurity in Timor-Leste. Food Security. 2013;5(1):83-94.

[42] International Fund for agricultural Development (IFAD). Improving food security in Timor-Leste to end 'hungry season', US\$5.6 million from IFAD for agricultural development. Newsroom Press Release: Press release No.: IFAD/37/2012. Available from: http://www.ifad.org/media/ press/2012/37.htm.

[43] Kelly M. Working with farmers for better agriculture in Timor-Leste. Proceedings of the Transforming Timor-Leste Conference. 6-7 July 2009. Available from: http://hdl.handle.net/ 10536/DRO/DU:30024764.

[44] World Health Organization (WHO). Global Health Observatory (2012). Available from: http:// www.who.int/gho/database/en/.

[45] Food and Agricultural Organization of the United Nations (FAO). Food Security Statistics, Prevalence of Undernourishment in Total Population (online database), 2012. Available from: http://www.fao.org/economic/ess/ess-fs/en/. In PDF available from: http://www.fao.org/ docrep/018/i3107e/i3107e02.pdf.

[46] World Health Organization Statistics (WHO 2012). Available from: http://www.who.int/ gho/publications/world_health_statistics/2012/en/ index.html.

[47] United Nations Children's Fund (UNICEF). The State of the World's Children 2011: Adolescence, an age of opportunity. New York, NY, February
2011.

[48] Central Intelligence Agency (CIA). The World Fact Book (2012). Timor-Leste. Washington, DC, USA: Central Intelligence Agency; 2013. Available from: https://www.cia.gov/library/publications/the-world-factbook/geos/tt.html.

[49] Ministry of Health $(\mathrm{MoH})$. Health profile. Dili, Timor-Leste: Ministry of Health; 2002. Available from: http://www.searo.who.int/timorleste/pub lications/Health_Information_TLS_Health_profile_ RDTL.pdf.

[50] Gupta I, Pradeep G. Communicable diseases in the South-East Asia region of the World Health Organization: Towards a more effective response. Bulletin of the World Health Organization. 2010;88(3)199-205.

[51] Martins N, Kelly PM, Grace JA, Zwi AB. Reconstructing Tuberculosis Services after Major Conflict: Experiences and Lessons Learned in East Timor. Public Library of Science (PLOS) Medicine. 2006;3(10):e383.

[52] Martins N, Kelly P. Food incentives to improve completion of tuberculosis treatment: Randomised controlled trial in Dili, Timor-Leste. British Medical Journal. 2009;339:b4248. Available from: http://www.bmj.com/content/339/ bmj.b4248.

[53] World Health Organization (WHO). Regional Office for South-East Asia. Country Profile: Timor-Leste. Communicable Disease Department, Tuberculosis. March 2009. Available from: http://www.searo.who.int/en/Section10/Section2 097/Section2100_14804.htm.

[54] Martins JS, Zwi AB, Martins N, Kelly PM. Malaria control in Timor-Leste during a period of politicalinstability: What lessons can be learned? Conflict and Health. 2009;3(11):1-10.

[55] Eddleston $M$, Davidson $R$, Brent A, Wilkinson R. Oxford Handbook of Tropical Medicine. Third Edition. Oxford, UK: Oxford University Press; 2010.

[56] Hotez PJ, Ehrenberg JP. Escalating the global fight against neglected tropical disease through interventions in the Asia Pacific region. Advances in Parasitology. 2010;72:31-53.

[57] World Health Organization (WHO). World Health Statistics 2011. Geneva, Switzerland. Joint Reporting Form. Available from: http://www. who.int/whosis/whostat/2011/en/index.html

[58] United Nations Children's Fund (UNICEF). At a Glance: Timor-Leste. Statistics. 2011. Available from: http://www.unicef.org/infobycountry/Timor leste_statistics.html

[59] United Nations (UN), Department of Economic and Social Affairs, Population Division 2009. World Population Prospects: The 2008 Revision, Highlights. New York, NY, USA. Working Paper No. ESA/P/WP.210.

[60] World Health Organization (WHO). WHO Vaccine 
Preventable Diseases: Monitoring System 2012: Global Summary. Available from: http://www. who.int/vaccines/globalsummary/immunization/ti meseries/tswucoveragedtp3.htm.

[61] Fritz V, Menocal AR. Developmental States in the New Millennium: Concepts and Challenges for a New Aid Agenda. Development Policy Review. 2007;25(5):531-552.

[62] Macrae J, Zwi A, Birungi $H$. A healthy peace? Restructuring and reform of the health sector in a post-conflict situation-the case of Uganda. London School of Hygiene and Tropical Medicine, and Makerere University, Uganda. In: Walt G. Health policy: an introduction to process and power. London, UK: Zed Books; 1993. pp. 84-85.

[63] Kruk ME, Freedman LP, Anglin GA, Waldman RJ. Rebuilding health systems to improve health and promote statebuilding in post-conflict countries: A theoretical framework and research agenda. Social Science and Medicine. 2010;70(1):89-97.
[64] Moyo D. Dead Aid: Why aid is not working and how there is a better way for Africa. New York, NY, USA: Farrar Straus \& Giroux; 2011.

[65] Da Costa H. G7+ and the New Deal: Country-Led and Country-Owned Initiatives: A perspective from Timor-Leste. Journal of Peacebuilding and Development, Special Issue: Hybridity in Peacebuilding and Development. 2012;7(2)96-102.

[66] Sahin SB. Building the nation in Timor-Leste and its implications for the country's democratic development. Australian Journal of International Affairs. 2011;65(2)220-242.

[67] Venancio AM, de Vasconselos A. Petroleum Fund of Timor-Leste: Quarterly Report. Timor-Leste. 2012;8(XXII).

[68] World Bank. Democratic Republic of Timor-Leste Joint Staff Advisory note on the Poverty Reduction Strategy Paper. 29 April 2005. Report No: 31924-TP, Volume 1. 
Appendix 1. List of Abbreviations

CAVR Comissão de Acolhimento, Verdade e Reconciliação (Commission for Reception, Truth and Reconciliation)

Csxxx composite score of the Failed States Index

EC European Commission

ESA Agricultural Development Economics Division

EU European Union

FSIxxxx Failed States Index

IMF International Monetary Fund

MDG Millennium Development Goals

OCHA Office for the Coordination of Humanitarian Affairs, United Nations

USAID United States Aid and International Development

WHO World Health Organization

WFP World Food Program

UN United Nations 